\title{
Pengetahuan mitigasi dan kapasitas kebencanaan melalui virtual meeting pada mahasiswa magister IPA Universitas Mataram
}

\author{
Kosim Kosim ${ }^{*}$, Muhamad Makhrus ${ }^{1}$, Aliefman Hakim² \\ ${ }^{1}$ Pendidikan Fisika, FKIP, Universitas Mataram, Mataram \\ 2 Pendidikan Kimia, FKIP, Universitas Mataram, Mataram \\ kosim_fisika@unram.ac.id
}

\begin{abstract}
NTB Province is one of the areas prone to natural disasters. In 2018 there was an earthquake that destroyed infrastructure and the safety of human life. The number of casualties due to the earthquake, one of which is the lack of public knowledge about disasters. Through counseling, the increase in knowledge and capacity to reduce disaster risk in science master students at the University of Mataram. It is hoped that students as intellectual agents in the community can continue or inform their environment. Data collection methods: before and after counseling, students were given a questionnaire via google form sent via WA regarding a) disaster knowledge, b) disaster risk reduction capacity and c) disaster mitigation measures. The discussion is more devoted to earthquake disasters. Outreach was held on November 5, 2020 virtually via zoom meeting. The number of participants who took part was 45 people, consisting of 16 male students and 29 female students. The results show that it is not satisfactory, because the percentage increase in knowledge at the high level is still smaller than the percentage level at the lower level. Therefore, it is suggested that education about disaster risk capacity still needs to be disseminated.
\end{abstract}

Keywords: natural disasters, disaster risk capacity, disaster mitigation

\begin{abstract}
Abstrak
Provinsi NTB merupakan salah satu wilayah yang rentan bencana alam. Pada tahun 2018 telah terjadi bencana alam gempa bumi yang memporak porandakan infrastruktur maupun keselamatan jiwa manusia. Banyaknya korban jiwa akibat gempa, salah satunya kurangnya pengetahuan masyarakat tentang kebencanaan. Melalui penyuluhan peningkatan pengetahuan dan kapasistas pengurangan resiko kebencanaan pada mahasiswa magister IPA Universitas Mataram. Hal ini, diharapkan bahwa mahasiswa sebagai agen intelektual dimasyarakat dapat meneruskan atau menginformasikan di lingkungan tempat tinggalnya. Metoda pengambilan data: sebelum dan sesudah penyuluhan mahasiswa diberikan quisioner melalui google form yang dikirim via WA mengenai a) pengetahuan kebencanaan, b) kapasitas pengurangan resiko bencana dan c) tindakan mitigasi bencana. Pembahasan lebih dikhususkan pada bencana gempa bumi. Penyuluhan telah dilaksanakan pada tanggal 5 November 2020 secara virtual via zoom meeting. Jumlah peserta yang mengikuti sebanyak 45 orang, terdiri dari mahasiswa laki 16 orang dan mahasiswa perempuan 29 orang. Hasil menunjukkan belum memuaskan, karena prosentase peningkatan pengethauan di level tinggi masih lebih kecil dari jumlah prosentase level dibawahnya. Oleh karena itu, disarankan penyuluhan tentang kapasitas resiko bencana masih perlu di sosialisasikan.
\end{abstract}

Kata Kunci: bencana alam; kapasitas resiko bencana; mitigasi bencana 


\section{PENDAHULUAN}

Mengingat NTB termasuk dalam wilayah yang rentan bencana alam, sehingga dalam peta Penanggulangan Bencana Alam, wilayah NTB merupakan prioritas. Penyuluhan mengenai peningkatan pengetahuan dan kapasistas dalam pengurangan resiko bencana pada mahasiswa magister IPA Uiversitas Mataram perlu diberikan, sehubungan mereka adalah termasuk masyarakat terdepan, melek ilmu dan dapat dipercaya oleh masyarakat dalam menyampaikan kembali pengetahuannya. Berdasarkan analisis situasi pada kurikulum mahasiswa baik S1 maupun S2 (Magister) di Universitas Mataram belum pernah ada sosialisasi mengenai peningkatan pengetahuan dan kapasitas dalam mengurasi resiko bencana alam. Penyuluhan ini penting dilakukan sehubungan dengan disadari atau tidak NTB khususnya di Pulau Lombok dan Pulau Sumbawa bagian Barat telah di guncang dengan hadirnya bencana gempa bumi terbaru tahun 2018.

Sebagaimana telah dirasakan bersama oleh masyarakat Lombok khususnya dampak dari bahaya bencana alam gempa bumi yang terjadi tahun 2018. Update terakhir jumlah korban jiwa menurut laporan BNPB 17 Agustus 2018 sesuai Tabel 1.

Tabel 1. Data Korban Jiwa Akibat Gempa Bumi Lombok 2018

\begin{tabular}{llcccrr}
\hline \multirow{2}{*}{ No. Kabupaten/ Kota } & Meninggal Dunia & Luka-luka & \multicolumn{3}{c}{ Mengungsi } \\
\cline { 5 - 7 } & & & 829 & 80.155 & 97.967 & 178.122 \\
\hline 1 & Lombok Utara & 404 & 122 & 46.857 & 57.233 & 104.060 \\
\hline 2 & Lombok Timur & 27 & 399 & 52.404 & 64.049 & 116.453 \\
\hline 3 & Lombok Barat & 39 & 0 & 6.085 & 7.803 & 13.877 \\
\hline 4 & Lombok Tengah & 2 & 63 & 8.503 & 10.931 & 18.894 \\
\hline 5 & Kota Mataram & 9 & 1.413 & 193.974 & 237.442 & 431.416 \\
\hline & Jumlah & 481 &
\end{tabular}

sumber : https://www.bnpb.go.id/indonesia-gempabumi-lombok

Data pada Tabel 1 tersebut hanya menunjukan kerugian korban jiwa, belum kerugian kerusakan harta benda. Berdasarkan laporan untuk menanggulangi gempa Lombok, menteri keuangan Sri Mulayani telah mencairkan Rp 985,8 miliar yang terdiri dari Rp 557,7 miliar melalui BNPB dan sebesar Rp 428,1 miliar melalui Kementerian/Lembaga, seperti Kementrian PUPR dan Kementerian Kesehatan (https://republika.co.id/berita/, Kamis 23 Agustus 2018).

Berdasarkan data dan informasi diatas, hendaknya mahasiswa yang merupakan bagian dari masyarakat intelek, perlu menjadi garda terdepan dalam upaya menyebarkan informasi pengetahuan kebencanaan dan upaya pengurangan resiko yang diakibatkan bencana, khususnya gempa bumi. Oleh karena itu, peran mahasiswa Unram menjadi penting dalam penyampaian informasi tentang kebencanaan, khususnya di daerah terdampak bencana. Masalah yang muncul dalam kegiatan ini adalah bagaimana masyarakat kampus khusunya Mahasiswa Magister IPA Universitas Mataram menanggapi upaya untuk meningkatkan pengetahuan kebencanaan, kapasitas resiko dan mitigasi dalam mengurangi dampak bencana alam 


\section{METODE PELAKSANAAN}

Pelaksanaan kegiatan pengabdian dalam masa pandemi ini telah dilakukan secara virtual melalui pertemuan zoom meeting, pada tanggal 5 November 2020. Dalam kegiatan tersebut telah dibantu oleh dua alumni mahasiswa Magister IPA sebagai Moderator dan Administrator kegiatan. Undangan di kirim melalui WhatsApp Group (WA grup) mahasiswa Magister IPA. Sehari sebelum pelaksanaan Zoom Meeting telah dikirim pula ke responden mahasiswa Magister IPA berupa informasi data responden dan quesioner tentang pengetahuan kebencanaan yang ditulis dalam google form. Data tersebut setelah dikirim oleh responden langsung tersimpan di alamat google drive milik kosimfisika@unram.ac.id.

Presentasi yang disampaikan dalam zoom meeting dibagi dalam 3 sesion masing-masing durasinya 30 menit. Presentasi Power point terdiri dari A) Pengetahuan Kebencanaan dan dampaknya, B). Kapasitas Pengurangan Resiko Kebencanaan dan C) Siaga Bencana sebagai upaya mitigasi bencana. Peserta Zoom Meeting diberi kesempatan untuk bertanya. Dalam selang pergantian sesion diputarkan video pendek berhubungan dengan pengetahuan kebencanan dengan durasi maksimum 5 menit. Bukti kegiatan virtual meeting ditampilkan dalam Gambar 1 berikut ini.

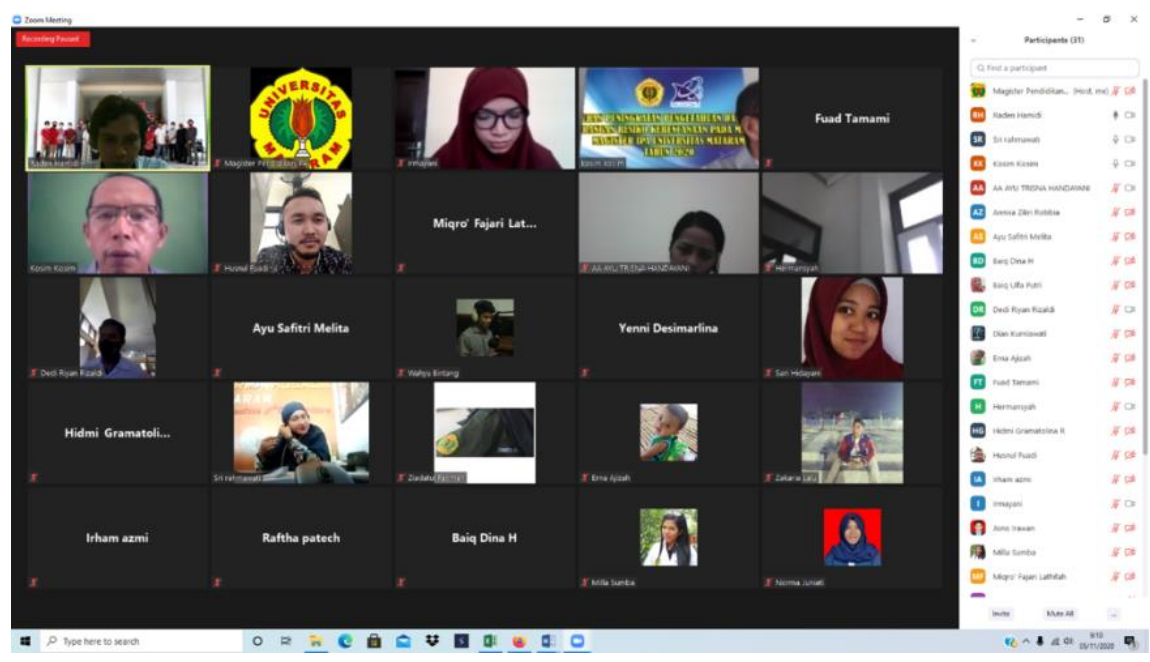

Gambar 1. Kegiatan Zoom Meeting

Berselang satu minggu setelah kegiatan Zoom Meeting, responden mengisi kembali kuesioner yang sama. Semua data yang terkumpul di olah dan dianalisa. Pengolahan terhadap data responden di dapat mengenai jumlah peserta zoom meeting, alamat tinggal mahasiswa dan jenis kelamin. Sedangkan untuk mengetahui klasifikasi tingkat penguasaan pengetahuan responden mengacu pada kriteria Tabel 2 berikut.

Tabel 2. Kriteria Peringkat Penguasaan Pengetahuan

\begin{tabular}{|c|c|c|}
\hline Tingkat & Kriteria & Keterangan \\
\hline Tinggi & $\geq \mathrm{MI}+0,5 \mathrm{SDI}$ & $\mathrm{MI}=(1 / 2)(\mathrm{Xmax}+\mathrm{Xmin})$ \\
\hline Cukup & $\mathrm{MI}-0,5 \mathrm{SDI} \mathrm{s} / \mathrm{d} \quad \mathrm{MI}+0,5 \mathrm{SDI}$ & $\mathrm{SDI}=(1 / 6)(\mathrm{Xmax}-\mathrm{Xmin})$ \\
\hline Kurang & $\leq \mathrm{MI}-0,5 \mathrm{SDI}$ & \\
\hline
\end{tabular}


(Riduwan, 2010)

\section{HASIL DAN PEMBAHASAN}

Sesuai apa yang dipaparkan dalam bagian pendahuluan, kegiatan pengabdian ini telah dilaksanakan kepada Mahasiswa Magister IPA Universitas Mataram pada tanggal 5 November 2020 melalui virtual meeting. Peserta peyuluhan pengetahuan mitigasi dan kapasitas pengurangan resiko kebencanaan pada mahasiswa magister IPA universitas Mataram telah di ikuti oleh 45 peserta. Jumlah peserta diketahui dari daftar absensi saat zoom meeting berlangsung, terdiri dari 16 mahasiswa laki dan 29 mahasiswa perempuan seperti yang ditunjukan pada gambar 2 berikut .

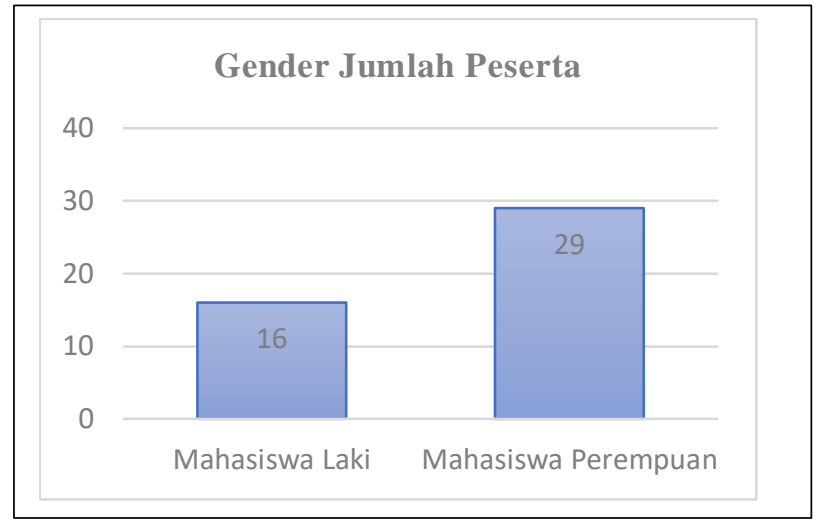

Gambar 2. Grafik gender jumlah peserta

Jika data responden diambil dari alamat tempat tinggalnya, diperoleh data peserta yang tinggal di wilayah Mataram 28 orang, di kabupaten Lombok Barat 7 orang, di kabupaten Lombok Tengah 7 orang dan Lombok Timur 3 orang. Sedangkan peserta dari Lombok Utara tidak ada, ini kemungkinan memang tak ada mahasiswa yang berasal dari Lombok Utara. Gambar 3 menunjukkan grafik asal peserta penyuluhan.

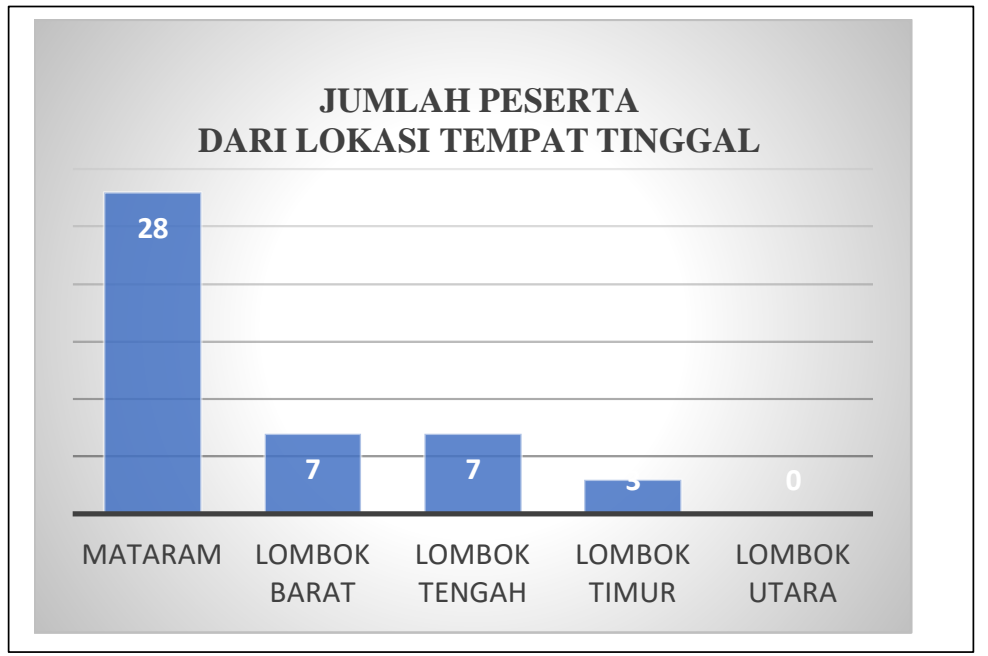

Gambar 3. Grafik asal peserta dalam Zoom Meeting

Data terhadap penguasaan pengetahuan mitigasi dan kapasitas pengurangan resiko bencana pada peserta penyuluhan melalui zoom meeting telah dianalisa berdasarkan kriteria tinggi, cukup dan kurang menurut Riduwan (2010), dimana Mean Ideal (DI) = 
66,5 dan Standar Deviasi Ideal (SDI) = 9,0 ditunjukkan oleh grafik pada gambar 4 dan 5 . Data tersebut di dapat sebelum dan setelah pelaksanaan zoom meeting.

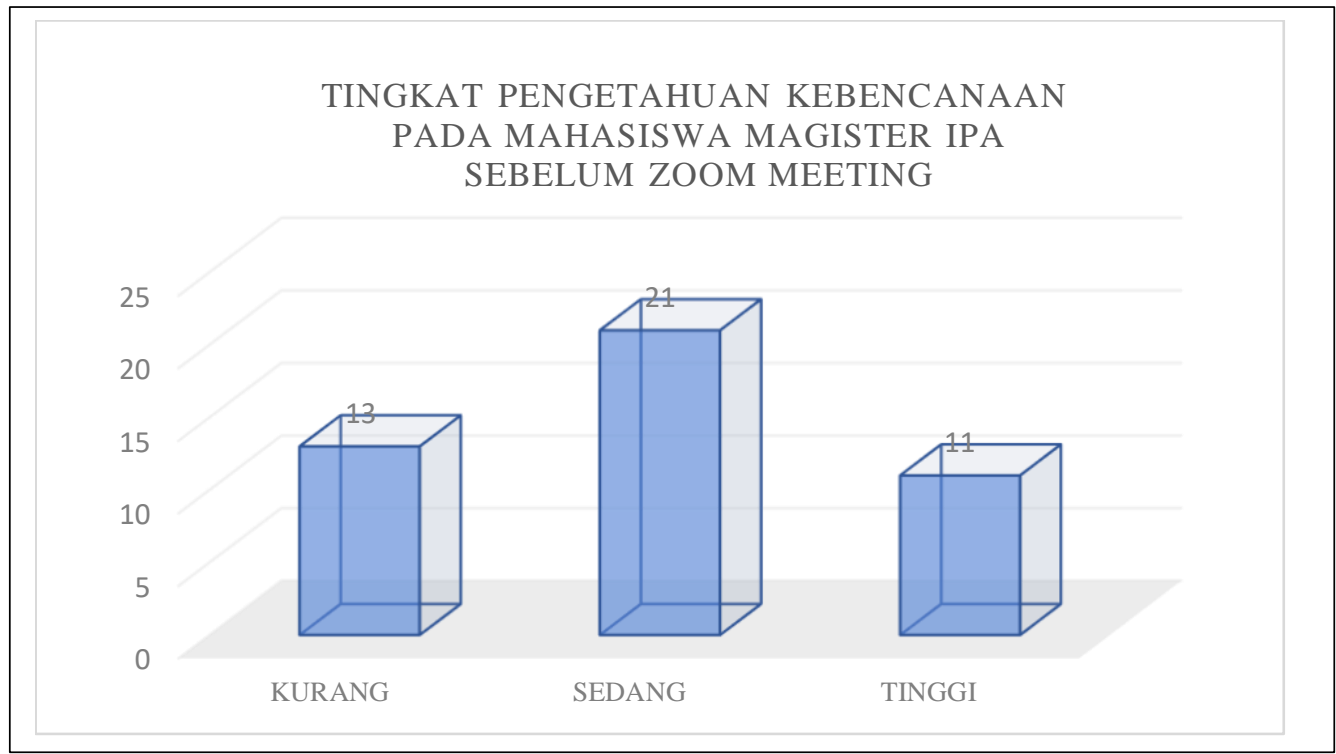

Gambar 4. Grafik tingkat pengetahuan kebencanaan sebelum Zoom Meeting

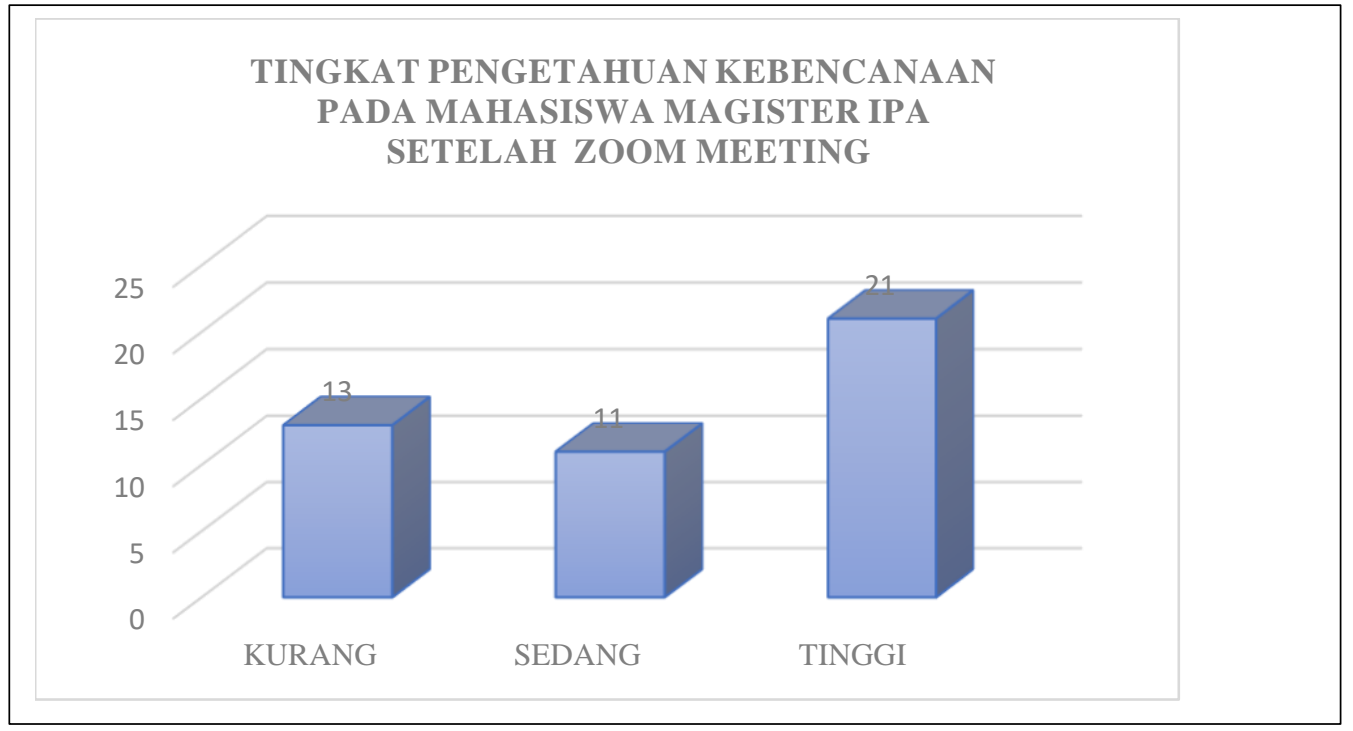

Gambar 5. Grafik tingkat pengetahuan kebencanaan setelah Zoom Meeting

\subsection{Keadaan Peserta Penyuluhan}

Berdasarkan data empiris peserta penyuluhan secara virtual dan dokumen sekunder dari prodi magister IPA, bahwa peserta yang terdiri dari 16 mahasiswa laki dan 29 mahasiswa perempuan merupakan mahasiswa yang masih aktif mengambil matakuliah pada angkatan 2019 dan angkatan 2020. Berdasarkan lokasi tempat tinggalnya, diperoleh data peserta yang tinggal di wilayah Mataram 28 orang, di kabupaten Lombok Barat 7 orang, di kabupaten Lombok Tengah 7 orang dan Lombok Timur 3 orang. Sedangkan peserta dari Lombok Utara tidak ada, memang pada angkatan tersebut tidak ada dari 
lombok utara. Semua peserta ini telah mengalami dan merasakan adanya gempa bumi dahysat pada bulan Agustus 2019 di Lombok. Mereka ada yang sudah bekerja sebagai guru dan lebih banyak mahasiswa yang baru lulus S1 lanjut ke jenjang S2.

Berbagai upaya untuk mensosialisasikan masalah mitigasi bencana dan kapasitas pengurangan resiko bencana telah banyak dilakukan. Bandan NasioanaPenanggulangan Bencana 1 (BNPB) dan Badan Penanggulangan Bencana Daerah (BPBD) diseluruh Indonesia telah melaksanakan berbagai sosialisasi ke masyarakat mengenai hal tersebut. Lembaga pemerintah yang terlibat dalam penanganan masalah bencana di bawah komando BNPB adalah Departemen Sosial, Departemen PUPR (Pekerjaan Umum Perumahan Rakyat), Departemen Kesehatan, Badan Meteorologi dan Geofisika (BMKG) dan BAPENAS. Sedangkan badan atau organisasi diluar pemerintah seperti Palang Merah Indonesia, SAR, organisasi ACT ( Aksi Cepat Tanggap), dan banyak lagi yang lainnya. Sedangkan organisasi dimasyarakat telah terbentuk Destana ( Desa Tangguh Bencana), KSB ( Kampung Siaga Bencana), kelompok masyarakat PRB (Pengurangan Resiko Bencana) dan banyak lagi. Pada perguruan tinggi yang peduli terhadap kebencanaan telah terbentuk pusat-pusat penelitian atau studi seperti SCDRM ( Studi Center Disaster Risk Management) di Fakultas Teknik Unram, PSBA (Pusat Stdi Bencana Alam ) di UGM, PPMB ( Pusat Penelitian Mitigasi Bencana) di ITB dan banyak lagi yang lainnya. Adapun sosialisasi secara langsung kepada mahasiswa Magister IPA Universitas Mataram belum tersentuh. Mereka sebagai mahasiswa berupaya secara mandiri dalam mendapatkan informasi mengenai bencana gempa bumi ini melalui media cetak maupun eletronik. Jumlah peserta kegiatan cukup banyak. Hal ini menunjukkan adanya minat yang tinggi dalam mendapatkan informasi mengenai kebencanaan.

\subsection{Tingkat Pengetahuan Kebencanaan pada Peserta}

Berdasarkan data grafik pada gambar 4 menunjukkan bahwa tingkat penguasaan pengetahuan kebencanaan pada mahasiswa magister IPA di dominasi pada tingkat sedang sebanyak 21 orang dan ternyata setelah melalui pertemuan zoom meeting dominan terjadi penguasaan pada level tinggi sebanyak 21 orang, dimana pada test awal dilevel ii hanya 11 orang. Artinya telah terjadi peningkatan pengetahuan kebencanaan pada mahasiswa magister IPA setelah kegiatan zoom meeting. Jika berdasarkan perbanding grafik pada gambar 4 dan 5 menunjukkan bahwa sebelum zoom meeting, ada 34 orang dibawah level tinggi dan setelah zoom meeting ada 24 orang di bawah level tinggi. Analisa terhadap pengetahuan setelah zoom meeting terdapat $(24 / 45) * 100 \%=$ $53,3 \%$ di bawah level tinggi dan $(21 / 45) * 100 \%=46,7 \%$ berada pada level tinggi. Hal ini menunjukkan bahwa hasil belum memuaskan, karena prosentase di level tinggi masih lebih kecil dari jumlah prosentase level dibawahnya.

Esperanza dan Samuel (2017) mengatakan bahwa kegiatan promosi dan pelatihan siaga bencana gempa bumi pada mahasiswa telah memberikan peningkatan tingkat pengetahuan gempa. Hal ini diartikan bahwa dengan adanya peningkatan pengetahuan dapat mengurangi resiko korban gempa. Sejalan dengan hasil penelitian Esperanza dan Samuel tersebut, maka dengan adanya penyuluhan tentang kebencanaan, walaupun 
secara virtual, diperkirakan dapat meningkatkan kapasitas mahasiswa dalam mengurangi resiko bencana gempa bumi yang terjadi di wilayahnya.

Budimanto et al. (2017), menyatakan bahwa terdapat hubugan yang signifikan antara variabel pengetahuan bencana dengan kesiapsiagaan dan antara variabel sikap dengan kesiapsiagaan terhadap bencana gempa bumi. Sebagai tujuan akhir dari kegiatan penyuluhan dimana telah terjadi peningkatan pengetahuan setelah adanya penyuluhan secara virtual, diharapkan pada peserta terjadi adanya perubahan sikap yang mendukung untuk adanya peningkatan terhadap kesiap siagaan gempa di wilayah NTB.

Upaya penyadaran dan sosialisasi kesiagaan terhadap dampak bencana alam telah dilakukan pula melalui sekolah di NTB, Syahrial dkk (2019), Kosim dkk (2019) I Wayan Gunada dkk (2020) dan Syahrial dkk (2020). Penyuluhan dan pembelajaran kebencanaan ini perlu disampaikan sedini mungkin, terutama melalui pendidikan seperti yang disampaikan Rusilowati dkk(2011), Ningtyas dan Duana (2018). Pelatihan mitigasi secara virtualpun bahkan dapat dilakukan (Mantasia dan Hendra Jaya, 2016).

Belum adanya pengetahuan kapan bencana gempa bumi itu akan terjadi, maka selayaknya kita harus selalu bersiap siaga. Kita sadari bahwa kita hidup berada di wilayah rawan bencana alam. Oleh karena itu proses pengingatan melalui sosialosasi dan pendidikan harus selalu digaungkan dan dilaksanakan. Semua upaya mitigasi dan peningkatan kapasitas kemampuan baik pemerintah maupun masyarakat harus terus di tingkatkan. Hal ini bertujuan sedikitnya dapat meminimalisir dampak akibat bencana.

\section{SIMPULAN}

Berdasarkan hasil dan pembahasan dapat disimpulkan bahwa mahasiswa Prodi Magister IPA memiliki minat yang cukup tinggi untuk mengetahui hal yang berhubungan dengan pengetahuan dan kapasitas pengurangan resiko kebencanaan. Hal ini ditunjukan dengan jumlah peserta yang yang mengikuti kegiatan via zoom meeting cukup banyak ( 45 orang). Pengetahuan peserta tentang kebencanaan mempunyai posisi dominan di level sedang sebelum Zoom Meeting. Tetapi setelah mengikuti zoom meeting dan dilakukan test ulang posisinya dominan di level tinggi. Artinya ada peningkatan pengetahuan pada peserta setelah penyuluhan. Berdasarkan analisa perbanding tingkat pengetahuan secara keseluruan sebelum dan setelah zoom meeting menunjukkan bahwa hasil penyuluhan belum memuaskan, karena prosentase di level tinggi (46,7\%) masih lebih kecil dari jumlah prosentase level dibawahnya (53,3\%). Saran atau rekomendasi yang bisa disampaikan dalam hal ini adalah pengaturan zoom meeting masih perlu perbaikan, walaupun ada moderator dan teknisi zoom, ternyata masih ada kendala teknis yang dialami. Selain itu kehadiran peserta zoom meeting belum bisa di jamin bahwa mereka benar benar hadir di depan layar, sehubungan video wajah (life) peserta banyak yang tidak dimunculkan. 


\section{UCAPAN TERIMA KASIH}

Terimakasih kepada Prodi Magister IPA Universitas Mataram yang telah membmendanai kegiatan pengabdian kepada masyarakat melalui surat perjanjian LPPM Unram sebagan dana PNBP tahun anggaran 2020. Berterimakasih juga kepada mahasiswa Magister IPA Universitas Mataram yang telah berperan aktif dalam zoom meeting sebagi peserta penyuluhan tentang Peningkatan Pengetahuan dan Kapasitas Pengurangan Resiko Kebencanaan. Tak lupa disampaikan terimakasih kepada Tim Dosen dan juga moderator dan teknisi yang telah mendukung tercapainya kegiatan tersebut.

\section{REFERENSI}

Ayub, S., Makhrus, M., Arduha, J., Verawati, N. N. S. P., \& Kosim, K. 2019. Kesiapsiagaan Bencana Gempabumi di SMP Negeri 2 Mataram. Prosiding PEPADU Seminar Nasional Pengabdian pada Masyarakat Universitas Mataram, e-ISSN: 2715-5811, Vol. 1. p. 273 - 281.

Budimanto, Mudatsir, \& Tahlil, T. (2017). Hubungan Pengetahuan, Sikap Bencana dan Keterampilan Basic Life Support dengan Kesiapsiagaan Bencana Gempa Bumi Pada Mahasiswa Keperawatan Poltekkes Banda Aceh. Jurnal Ilmu Kebencanaan (JIKA). Pasca Sarjana Syiahkuala. ISSN: 2355-3324. Vol. 4(2). p. 53-58.

Esperanza, Ayub, \& Simanjutak, S. M. (2020). Pengetahuan tentang Kesiagaan Bencana Melalui Promosi dan Pelatihan Siaga Gempa. Media Karya Kesehatan. Vol. 3 No.1. Universitas Advent Indonesia.

Gunada, I.W., Ayub, S., Doyan, A., Taufik, M., \& Kosim, K. 2020. Development of Disaster Mitigation Learning Structures. Jurnal Penelitian Pendidikan IPA. DOI: 10.29303 /jppipa.v6i1.324, Vol. 6(1). p.69-74.

Kosim, K., Ayub, S., Gunada, I. W., \& Handayani, E. P. (2019). Audio Visual Based Learning on Landslide and Tsunami Mitigation in fifth Grade Students at State Primary School (SDN) 6 Mataram. Proceedings of the 1st Annual Conference on Education and Social Sciences. Atlantis Press. Vol. 465.

Mantasia \& Jaya, H. 2016. Model Pembelajaran Kebencanaan Berbasis Virtual Sebagai Upaya Mitigasi dan Proses Adaptasi Terhadap Bencana Alam di SMP Jurnal Penelitian Pendidikan Paedagogia. ISSN 0126-4109. Vol. 19(1). p. 1-14.

Ningtyas, D.P., \& Duana, F.R. 2018. Pengembangan Permainan Sirkuit Mitigasi Bencana Gempa Bumi Untuk Meningkatkan Self Awareness Anak Usia Dini. Jurnal Caksana-Pendidikan Anak Usia Dini. Vol. 1 (2). P. 172 - 187.

Rusilowati, A, Supriyadi, A. Binadja, Mulyani. 2012. Mitigasi Bencana Alam Berbasis Pembelajaran Bervisi Science Environment Technology And Society. Jurnal Pendidikan Fisika Indonesia. ISSN: 1693-1246. Vol. 8. p. 51-60.

Riduwan. 2010. Dasar-Dasar Statistika. Alfa Beta. Bandung.

Website PNBP provinsi NTB di akses 5 Maret 2020: https://www.bnpb.go.id/indonesiagempabumi-lombok.

Website Koran Republika diakses 5 Maret 2020: https://republika.co.id/berita/, (berita tertanggal kamis 23 Agustus 2018). 